\title{
About the conference
}

Dear colleagues!

The Research Network on the Resource Economics and Bioeconomy Association (RebResNet) in partnership with the local organization branch has organized The 3rd International Conference on Resources Economics and Bioeconomy in Competitive Societies (RebCos'20) under the title Environmental Challenges, Innovative Technologies and Rural Areas in Digital Era in Belgrade, RS Serbia, on 16th October 2020.

I am glad to see all of you as the contributors of the RebCos '20. Today participation in a regular scientific event is not just a matter of planning but a matter of personal involvement, devotion and flexibility. Thank you so much for staying with us in these times of uncertainty.

The conference aims was to provide a general framework and opportunity for researchers, academics, policy makers and professionals from all business, economics and engineering curricula to meet, present and discuss key issues related to environmental challenges, business, innovative technologies and rural areas in digital era.

For years we have been talking about the challenges to be responded globally. They used to be related to environmental issues mostly. COVID-19 turned out a manifestation of the need for joining efforts. Governments are struggling to find a solution to provide for the peoples' infectious safety, but what really matters is the individual responsibility and commitment. This is a new step towards networking instead of building hierarchy-based structures. We ought to be actors to make a difference.

Bio-based economy has done good to prove that sustainable development is not a dystopia, although we know that it still needs enormous efforts, creativity and audacity to make all aspects of our life safe for the planet and profitable for global economy. Today we cannot deny that the pandemic has been embedded into the system of environmentally-related issues. It shifts the optics but does not remove the goal.

The lockdown has set barriers for movement of goods, capitals and human recourses, threatened food security and transformed the mainstream consumption policies. The dramatic lifestyle changes resulted in an overall reappraisal of values.

The specific objective of the RebCos conferences is to generate a discussion forum and debating on the most actual and recent challenges, opportunities, constrains and perspectives in resources economics and bioeconomy area and to support further developments of a bio-based economy. 
RebResNet is a network of scholars and professionals who are positively intended and feel individual responsibility for making a contribution, a step forward. We hope that soon our members will be able to make these steps about all continents.

The conference welcomes empirical research as well as theoretical/conceptual or practical research papers consistent with the RebCos conferences aims and scopes. Conference participants are encouraged to submit full length research, short communications and reviews, invited session proposals. All the submitted manuscripts were subject to a double blind review process and it was fully refereed.

We welcome all of you to join all the events we offer to promote the cutting-edge research results you achieve. We do hope that we will be able to come back to a face-to-face (not a mask-to-mask / screen-to-screen) format. We do hope to host you offline next time.

\section{CONFERENCE PROGRAM CHAIRS}

Dorel Dusmanescu, Petroleum-Gas University of Ploiesti, Romania Jovan Zubovic, Institute of Economic Sciences, Serbia

\section{VICE-CHAIRS}

Aleksandar Grubor, University of Novi Sad, Faculty of Economics in Subotica, Serbia

Natalia Staurskaya, Omsk State Technical University, Russian Federation

\section{CONFERENCE SCIENTIFIC PARTNERS}

The Institute of Agricultural Economics (IAE), Belgrade, RS Serbia

National Institute of Economic Research 'Costin C. Kiriţescu' (INCE), Romania

The Institute of Economic Sciences (IES), Belgrade, Serbia

Institute of Agricultural Economics and Rural Development, Republika

Srpska,Bosnia and Herzegovina

\section{SCIENTIFIC BOARD}

Aleksandr Arskiy, Russian Academy of Staffing Support in Agriculture, Russian Federation

Drago Cvijanović, University of Kragujevac, RS Serbia

Anna Ivolga, Stavropol State Agrarian University, Russian Federation

Biljana Petrevska, Universty"Goce Delcev" -Stip, North Macedonia

Luminita Chivu, National Institute for Economics Research, Romania

Donatella Privitera, University of Catania, Italy

Halil İbrahim Aydın, Batman University, Turkey

Ignacio De Los Ríos Carmenado, Universidad Politécnica de Madrid, Spain

Ileana Georgiana Gheorghe, Petroleum-Gas University of Ploiești, Romania

Marko Jelocnik, Institute of Agricultural Economics, Serbia

Silvius Stanciu, Dunarea de Jos University of Galati, Romania 
Simona Monteleone, University of Catania, Italy

Alla Konobeeva, Russian Academy of Staffing Support in Agriculture, Russian Federation

Mostafa Ibrahim, University of Kafrelsheikh, Egypt

Snezana Bardarova, Universty"Goce Delcev" -Stip, North Macedonia

Teodor Sedlarski, St Kliment Ohridski University of Sofia, Bulgaria

Tianming Gao, Harbin Engineering University, China

Violeta Sima, Petroleum-Gas University of Ploiești, Romania

Zeljko Vasko, University of Banja Luka, Bosnia and Herzegovina

Zorica Vasiljevic, University of Belgrade, Serbia

Olga Zhiltsova, Financial University under the Government of the Russian Federation, Russian Federation

Marija Kostić, University of Kragujevac, RS Serbia

Nancu Dumitru, Ovidius University of Constanta, Romania

Dejan Sekulić, University of Kragujevac, RS Serbia

Mikail Khudzhatov, RUDN University, Russia

Darko Marjanović, Institute of Economic Sciences, Belgrade

Anna Veber, Omsk State Agrarian University, Russian Federation

Lădaru Georgiana Raluca, Bucharest University of Economic Studies, Romania

Vesna Parausic, Institute of Economics Agriculture, Serbia

Magdalena Turek Rahoveanu, Dunarea de Jos University of Galati, Romania

Vlado Kovacevic, Institute of Economics Agriculture, Serbia

Aniela Balacescu, Constantin Brâncusi University of Târgu Jiu, Romania

Svetlana Roljevic Nikolic, Institute of Economics Agriculture, Serbia

Stefan Ghimisi, Constantin Brâncusi University of Târgu Jiu, Romania

Predrag Vukovic, Institute of Economics Agriculture, Serbia

\section{Yours sincerely,}

\section{Proceedings editor(s):}

Andrei Jean Vasile, Petroleum-Gas University of Ploiești, Romania

Vasilii Erokhin, Harbin Engineering University, China

Adrian Turek Rahoveanu, University of Agronomic Sciences and Veterinary

Medicine, Romania

Jonel Subić, Institute of Economics Agriculture, Serbia

Mihaela Cristina Dragoi, Bucharest University of Economic Studies, Romania

Natalia Staurskaya, Omsk State Technical University, Russian Federation

Dorel Dusmanescu, Petroleum-Gas University of Ploiesti, Romania 